\title{
Improved Science Learning Outcomes of Relationship Between Ecosystem Components through Audio Visual Media
}

\section{Dhessriyatno Fajar Nugroho}

SD Negeri Kaliwiru Semarang

sdkaliwiru@yahoo.co.id

\section{Article History}

accepted $14 / 11 / 2020$

\begin{abstract}
The purpose of this study is to improve student learning outcomes on the material relations between components of ecosystems and food webs. This research is a classroom action research (PTK) which is conducted in three cycles, each cycle consisting of planning, implementation, observation, and reflection stages. The subjects of this study were the fifth grade students of SD Negeri Kaliwiru Semarang in the 2020/2021 school year, totaling 24 students. Data collection techniques, data presentation, and drawing conclusions. Research shows that the application of audio-visual learning media can improve student learning outcomes on the material on the relationship between ecosystem components and food webs in class V SD Negeri Kaliwiru in the 2020/2021 academic year as evidenced by the percentage of learning outcomes in cycle I of $37.5 \%$, in cycle II amounted to $91.5 \%$ and cycle III $95.8 \%$.
\end{abstract}

Keywords: audio visual, ecosystem components, student

\section{Abstrak}

Tujuan penelitian ini adalah untuk meningkatkan hasil belajar siswa pada materi hubungan antar komponen eksosistem dan jaring-jaring makanan. Penelitian ini merupakan penelitian tindakan kelas (PTK) yang dilaksanakan dalam tiga siklus, setiap siklus terdiri dari tahap perencanaan, pelaksanaan, observasi, dan refleksi. Subjek penelitian ini adalah peserta didik kelas V SD Negeri Kaliwiru Semarang tahun pelajaran 2020/2021 yang berjumlah 24 peserta didik. Teknik pengumpulan data, penyajian data, dan penarikan kesimpulan. Penelitian menunjukkan bahwa penerapan media pembelajaran audio visual dapat meningkatkan hasil belajar siswa pada materi hubungan antar komponen ekosistem di kelas V SD Negeri Kaliwiru tahun pelajaran 2020/2021 yang dibuktikan dengan persentase ketuntasan hasil belajar pada siklus I sebesar $37,5 \%$, pada siklus II sebesar $91,5 \%$ dan siklus III 95,8 \%.

Kata kunci: audio visual, komponen ekosistem, siswa

Social, Humanities, and Education Studies (SHEs): Conference Series https://jurnal.uns.ac.id/shes 


\section{PENDAHULUAN}

IImu Pengetahuan Alam erat kaitannya dengan lingkungan belajar peserta didik. IPA mulai diperkenalkan dari tingkat SD dengan berbagai materi seperti gejala alam dan fenomena alam. Menurut KTSP 2006 (dalam Sulistyorini, 2007:9) pada hakekatnya IPA dapat dipandang dari segi produk, proses, dan dari segi pengembangan sikap. Artinya belajar IPA memiliki dimensi proses, dimensi hasil (produk), dan dimensi pengembangan sikap ilmiah. Ini berarti bahwa proses belajar mengajar IPA seharusnya mengandung tiga dimensi tersebut.

IImu Pengetahuan Alam ( IPA ) merupakan salah satu mata pelajaran di SD yang berhubungan dengan cara mencari tahu tentang alam secara sistematis, sehingga IPA bukan hanya penguasaan kumpulan pengetahuan yang berupa faktafakta, konsep-konsep, atau prinsip-prinsip saja tetapi juga merupakan suatu proses penemuan yang melibatkan keaktifan peserta didik.

Pendidikan IPA diharapkan dapat menjadi wahana peserta didik untuk mempelajari diri sendiri dan alam sekitar, serta prospek pengembangan lebih lanjut dalam menerapkannya di dalam kehidupan sehari-hari. Proses pembelajaran IPA menekankan pada pemberian pengalaman langsung untuk mengembangkan kompetensi agar menjelajahi dan memahami alam sekitar secara ilmiah (Depdiknas, 2008:147).

Menurut Cullingford dalam pembelajaran IPA anak harus diberi kesempatan untuk mengembangkan sikap ingin tahu. Hal ini akan mendorong anak untuk mengembangkan cara berfikir logis. Sedangkan menurut Claxton menyatakan bahwa kualitas pembelajaran IPA dapat ditingkatkan, bila anak berkelakuan sebagai seorang ilmuwan. Mereka memahami konsep baru dengan lebih mudah dan menyenangkan melalui suatu percobaan (Samatowa, 2006:9).

Salah satu kelemahan pembelajaran IPA di SD selama ini adalah bahwa pembelajaran tersebut lebih menekankan pada penguasaan sejumlah fakta dan konsep, dan kurang memfasilitasi peserta didik agar memiliki hasil belajar yang comprehensive. Seringkali pembelajaran IPA bahkan dilaksanakan dalam bentuk latihan-latihan penyelesaian soal-soal, semata-mata dalam rangka mencapai target nilai evaluasi hasil belajar sebagai "ukuran utama" prestasi peserta didik dan kesuksesan guru dalam mengelola pembelajaran. Pembelajaran IPA seharusnya menekankan pada penguasaan kemampuan dasar kerja ilmiah atau keterampilan proses IPA.

Berdasarkan temuan Depdiknas (2007), masih banyak permasalahan pelaksanaan standar isi mata pelajaran IPA. Pemahaman guru terhadap SK-KD sangat beragam, karena latar belakang pendidikan, daerah, kapasitas, kompetensi sehingga guru kesulitan memahami dan memaknai SK-KD dalam implementasi pembelajaran. Kebiasaan guru "taken for granted" dari pusat memperlemah kreativitas dan inovasi mereka dalam mengembangkan pembelajaran. Guru menerapkan pembelajaran lebih menekankan strategi mengaktifkan guru, kurang melibatkan peserta didik, pembelajaran kurang kreatif, lebih banyak menggunakan strategi konvensional (ceramah) dan kurang mengoptimalkan media pembelajaran. Hal ini menyebabkan peserta didik kurang aktif mengikuti proses pembelajaran, bahkan cenderung pasif. Peserta didik hanya diam saja, mendengarkan, mencatat, dan mudah bosan dalam pembelajaran.

Permasalahan yang dikemukakan Depdiknas merupakan gambaran umum permasalahan praktik pembelajaran IPA. Setelah melaksanakan kegiatan pembelajaran secara langsung, wawancara dan observasi bersama kolaborator, diketahui permasalahan hampir serupa terjadi di kelas V SD Kaliwiru Semarang. Saat menyampaikan materi, guru belum optimal menerapkan media pembelajaran inovatif, khususnya yang cocok diterapkan pada mata pelajaran IPA. Hal tersebut berdampak langsung terhadap aktivitas peserta didik yang cenderung rendah. Peserta didik 
menganggap IPA bersifat teoritis dan hafalan sehingga kurang antusias mengikuti pembelajaran. Peserta didik terlihat berdiam diri ketika guru memberi pertanyaan. Beberapa peserta didik justru bermain sendiri, menggambar di buku tulis, mengobrol dengan teman sebangku tanpa memperhatikan penjelasan materi yang disampaikan guru.

Proses pembelajaran seperti di atas berdampak pada hasil belajar peserta didik. Berdasarkan hasil tes menunjukkan sebagian besar pencapaian hasil belajar peserta didik kelas $\mathrm{V}$ mata pelajaran IPA masih di bawah Kriteria Ketuntasan Minimal (KKM) yaitu 65. Sebanyak $70 \%$ atau 17 dari 24 siswa kelas $\mathrm{V}$ mendapatkan nilai di bawah 65 , nilai terendah 40 , nilai tertinggi 80 , rata-rata kelas 60,33.

Memperhatikan permasalahan tersebut selayaknya dalam pembelajaran dilakukan suatu inovasi yaitu pembelajaran dengan menggunakan media audio visual. Secara umum media audio visual menurut teori kerucut pengalaman Edger Dale memiliki efektivitas yang tinggi dari pada media visual atau video (Sukiman, 2012:184). Sedangkan menurut Sanjaya (2016:118) media audio visual, yaitu jenis media yang selain mengandung unsur suara juga mengandung unsur gambar yang dilihat, seperti misalnya rekaman video, berbagai ukuran film, slide suara dan lain sebagainya. Kemampuan media ini dianggap lebih baik dan lebih menarik, sebab mengandung kedua unsur jenis media yang pertama dan kedua.

Media berbasis audio visual adalah media visual yang menggabungkan penggunaan suara dan memerlukan pekerjaan tambahan untuk memproduksinya. Salah satu pekerjaan penting yang diperlukan dalam media audio visual adalah penulisan naskah dan storyboard yang memerlukan persiapan yang banyak, rancangan, dan penelitian (Arsyad, 2014:91).

Sanjaya (2012:109) menyatakan bahwa terdapat beberapa kelebihan penggunaan audio visual dalam proses pembelajaran diantaranya sebagai berikut.

a) Audio visual dapat memberikan pengalaman belajar yang tidak mungkin dapat dipelajari secara langsung.

b) Audio visual memungkinkan belajar lebih bervariatif sehingga dapat menambah motivasi.

c) Dalam batas tertentu audio visual dapat berfungsi sebagai sumber belajar yang dapat dimanfaatkan peserta didik untuk belajar secara mandiri tanpa sepenuhnya tergantung pada kehadiran guru.

Kekurangan dari media audio visual berjenis film dan video adalah sebagai berikut.

1) Terlalu menekankan pentingnya materi ketimbang proses pengembanganya dan tetap memandang materi audio visual sebagai alat bantu guru dalam mengajar.

2) Media audio visual tidak dapat digunakan dimana saja dan kapan saja, karena media audio visual cenderung tetap di tempat

3) Media audio visual cenderung menggu-nakan model satu arah

Dalam kegiatan pembelajaran atau kegiatan instruksional, biasanya guru menetapkan tujuan belajar. Anak yang berhasil dalam belajar adalah yang berhasil mencapai tujuan-tujuan pembelajaran atau tujuan instruksional. Menurut Djamarah dan Zain (2010: 105) untuk menyatakan bahwa suatu proses pembelajaran dapat dikatakan berhasil bila setiap guru memiliki pandangan masing-masing sejalan dengan filsafatnya.

Evaluasi hasil belajar adalah keseluruhan kegiatan pengukuran (pengumpulan data dan informasi), pengolahan, penafsiran dan pertimbangan untuk membuat keputusan ten-tang tingkat hasil belajar yang dicapai oleh siswa setelah selesai melakukan kegiatan belajar dalam upaya mencapai tujuan pembel-ajaran yang telah ditetapkan. Hasil belajar menunjukkan pada prestasi belajar, sedangkan prestasi belajar itu merupakan indikator adanya dan derajat perubahan tingkah laku peserta didik. 
Berdasarkan uraian di atas penulis mencoba melakukan penelitian dengan judul Peningkatan Hasil Belajar IPA Materi hubungan antar komponen ekosistem melalui media pemebelajaran audio visual.

\section{METODE}

Penelitian ini dilaksanakan dalam tiga siklus. Setiap siklus terdiri atas empat tahap meliputi perencanaan, pelaksanaan tindakan, observasi, dan refleksi. Subjek penelitian yaitu guru dan peserta didik kelas V SD Negeri Kaliwiru Semarang, terdiri atas 11 peserta didik laki-laki dan 13 peserta didik perempuan. Faktor penelitian meliputi keterampilan guru, aktivitas peserta didik, dan hasil belajar peserta didik dalam pembelajaran materi hubungan antar komponen ekosistem. Teknik pengumpulan data menggunakan teknik tes dan nontes. Teknik analisis data menggunakan data kuantitatif dan kualitatif.

Teknik kuantitatif diperoleh dari hasil kognitif peserta didik setiap siklusnya, dengan memberikan tes pengetahuan dalam bentuk google form pada setiap akhir siklusnya. Teknik kualitatif diperoleh dari data hasil observasi keterampilan guru dan aktivitas peserta didik dalam pembelajaran materi hubungan antar komponen ekosistem, serta hasil catatan lapangan dengan analisis diskriptif kualitatif.

\section{HASIL DAN PEMBAHASAN}

Adapun pelaksanaan penelitian dengan menggunakan media pembelajaran audio visual pembelajaran IPA materi hubungan antar komponen ekosistem kelas $\mathrm{V}$ SD Negeri Kaliwiru Semarang, siklus I diadakan pada hari Senin tanggal 2 November 2020, kemudian siklus II pada hari Senin tanggal 9 November 2020, dan siklus III pada hari Jumat tanggal 20 November 2020. Setiap siklus dilaksanakan dalam empat tahap yaitu tahap perencanaan, pelaksanaan tindakan, observasi, dan refleksi.

Tahap perencanaan yang dilakukan peneliti adalah menyusun beberapa instrumen penelitian yang akan digunakan dalam tindakan dengan menerapkan media pembelajaran audio visual dalam menyampaikan materi hubungan antar komponen ekosistem. Penggunaan media pembelajaran audio visual diharapkan dapat meningkatkan hasil belajar peserta didik terhadap materi yang diajarkan. Perangkat pembelajaran dan instrument yang dipersiapkan meliputi: Rencana Pelaksanaan Pembelajaran (RPP), Lembar Kerja Peserta Didik (LKPD), soal evaluasi dan lembar observasi. Observasi aktivitas peserta didik dalam pembelajaran dilakukan melalui lembar observasi, dan untuk penilaian terhadap hasil belajar peserta didik dengan melakukan evaluasi menggunakan tes google form pada setiap siklus.

Pelaksanaan Tindakan, guru (peneliti) menyampaikan materi hubungan antar komponen ekosistem. Kegiatan ini dilaksanakan dengan langkah-langkah pembelajaran yang dilakukan oleh guru sesuai dengan Rencana Pelaksanaan Pembelajaran (RPP) yang sudah dibuat berdasarkan analisis hasil penelitian yang telah diuraikan pembahasan pada penelitian Kegiatan ini dilaksanakan langkahlangkah pembelajaran yang dilakukan sesuai dengan rencana yang sudah dibuat, yaitu dari kegiatan awal dengan guru membuka pelajaran dengan berdoa dan menanyakan kabar peserta didik dan menyampaikan tujuan pembelajaran. Kemudian kegiatan inti dengan guru menjelaskan materi pembelajaran yaitu hubungan antar Komponen ekosistem dan jaring-jaring makanan melalui media pembelajaran audio visual. Serta kegiatan akhir yaitu peserta didik menyimpulkan materi yang sudah dipelajari dibimbing oleh guru. Dilanjutkan Peserta didik mengerjakan lembar evaluasi melalui google form secara individu. Untuk tindak lanjut guru menutup pelajaran dengan pesan-pesan dan menyampaikan materi yang akan dipelajari pada pertemuan berikutnya kepada peserta didik.

Observasi dilakukan guru ( peneliti ) dengan teman sejawat. Pada kegiatan observasi yang diamati adalah keaktifan peserta didik, tanggungjawab peserta didik 
serta guru dalam proses pembelajaran serta peristiwa-peristiwa yang terjadi pada waktu pembelajaran berlangsung. Berdasarkan hasil pengamatan, proses pembelajaran sudah cukup baik. Peserta didik antusias dalam mengikuti pembelajaran. Didukung media pembelajaran yang cukup baik, peserta didik sangat aktif dalam bertanya jawab dan merasa senang. Pada waktu mengamati media pembelajaran melalui media audio visual peserta didik sangat antusias. Guru memperhatikan kegiatan peserta didik dan membimbing peserta didik. Interaksi antara guru dan peserta didik terjalin sangat baik. Lembar Kerja Peserta Didik dan lembar evaluasi dalam Google Form dikerjakan peserta didik untuk mengukur keberhasilan pembelajaran yang telah dilaksanakan. Ada hal yang perlu diperhatikan oleh guru, pada waktu pembelajaran melalui WA berlangsung masih ada peserta didik yang masih pasif, hendaknya guru memotivasi anak tersebut supaya mau melakukan kegiatan dengan aktif. Guru ( peneliti ) dan teman sejawat mengadakan evaluasi dan refleksi dari kegiatan perencanaan, pelaksanaan dan observasi.

Diadakannya refleksi ini diharapkan dapat menemukan kekurangan dan kelebihan selama proses pembelajaran berlangsung sehingga dapat digunakan untuk meningkatkan pembelajaran selanjutnya. Pada setiap siklus diperoleh data kualitatif dan kuantitatif, yang termasuk data kualitatif yaitu : lembar keaktifan peserta didik dan lembar kinerja guru. Sedangkan data kuantitatif yaitu nilai hasil belajar peserta didik. Nilai hasil belajar peserta didik diperoleh melalui tes tertulis, Pada setiap akhir kegiatan pembelajaran siklus, diadakan tes untuk mengetahui hasil belajar peserta didik tentang hubungan antar komponen ekosistem. Adapun hasil belajar peserta didik pada tiap siklus seperti pada tabel dibawah ini.

Hasil peneltian menunjukkan peningkatan hasil belajar pada materi hubungan antar komponen ekosistem dan jaring-jaring makanan terlihat pada tabel berikut :

Tabel 1. Peningkatan Hasil Belajar

\begin{tabular}{c|c|c|c|c|c|c}
\hline \multirow{2}{*}{ Nilai } & \multicolumn{2}{|c|}{ Siklus I } & \multicolumn{2}{c|}{ Siklus II } & \multicolumn{2}{c}{ Siklus III } \\
\cline { 2 - 7 } & $\mathrm{f}$ & $\%$ & $\mathrm{f}$ & $\%$ & $\mathrm{f}$ & \\
\hline 100 & 0 & 0 & 1 & 4,2 & 6 & 25 \\
90 & 1 & 4,2 & 3 & 12,5 & 5 & 20,8 \\
80 & 4 & 16,7 & 14 & 58,3 & 5 & 20,8 \\
70 & 4 & 16,7 & 4 & 16,6 & 7 & 29,2 \\
60 & 5 & 20,7 & 1 & 4,2 & 1 & 4,2 \\
50 & 9 & 37,5 & 1 & 4,2 & 0 & 0 \\
40 & 1 & 4,2 & 0 & 0 & 0 & 0 \\
Jumlah & 24 & 100 & 24 & 100 & 24 & 100 \\
Rata-Rata & 62 & - & 78 & - & 83 & - \\
Tuntas & 9 & 37,5 & 22 & 91,5 & 23 & 95,8 \\
\hline
\end{tabular}




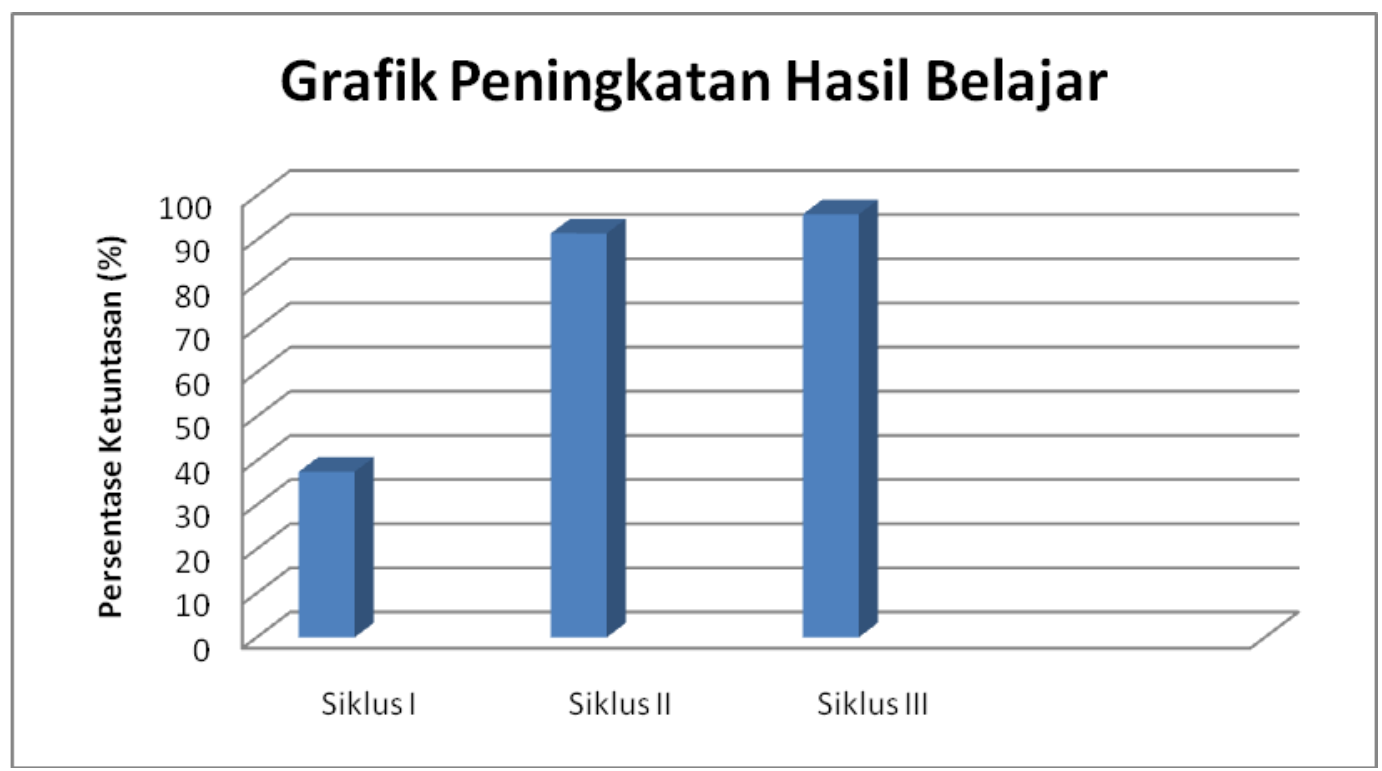

Gambar 1. Grafik Peningkatan Hasil Belajar

Peningkatan hasil belajar IPA peserta didik pada materi Hubungan antar komponen ekosistem diukur dengan menggunakan teknik tes hasil belajar dengan instrument lembar soal pada google form. Teknik pengumpulan data hasil belajar peserta didik diterapkan melalui tiga siklus. Penggunaan media pembelajaran audio visual dalam pembelajaran IPA dapat meningkatkan hasil belajar peserta didik di kelas V SD Negeri Kaliwiru secara signifikan. Pada hasil Penilaian sebelumnya terdapat 17 dari 24 peserta didik yang belum mencapai KKM dengan persentase ketuntasan hasil belajar hanya $30 \%$. Setelah dilakukan tindakan, persentase ketuntasan hasil belajar pada siklus I meningkat menjadi $37,5 \%$, dengan rata-rata kelas 62 . Pada siklus II terjadi peningkatan menjadi $91,5 \%$ dengan rata-rata kelas 78 , dan pada siklus III mencapai $95,8 \%$ dengan rata-rata kelas 83 . Pada siklus I belum mencapai indikator kinerja penelitian yang ditetapkan. Hasil belajar pada siklus II telah mencapai indikator kinerja penelitian dan terus meningkat hingga pada siklus III. Pada siklus III, ketuntasan hasil belajar IPA peserta didik telah mencapai 95,8\% dengan KKM 65 sehingga pelaksanaan tindakan dapat dihentikan.

Berdasarkan analisis hasil belajar peserta didik setelah pelaksanaan tindakan, dapat diambil kesimpulan bahwa penggunaan media pembelajaran audio visual dapat meningkatkan hasil belajar IPA pada materi hubungan antar komponen ekosistem. Hal ini sesuai dengan hasil penelitian yang dilakukan oleh Hana Rohana dan Junaedi Nugroho yang membuktikan bahwa penggunaan media audio visual dapat meningkatkan hasil belajar IPA secara signifikan. Hasil ini juga memperkuat pendapat Susanto (2016: 5) mengatakan bahwa hasil belajar adalah perubahan yang terjadi pada diri peserta didik, baik yang meyangkut aspek kognitif, afektif, dan psikomotor sebagai hasil dari kegiatan belajar. Peserta didik dapat menyerap dan mengingat materi dengan optimal, karena daya serap dan daya ingat peserta didik akan meningkat secara signifikan jika proses pemerolehan informasi awalnya lebih besar melalui indera penglihatan dan pendengaran. 


\section{SIMPULAN}

Berdasarkan hasil penelitian tindakan kelas yang dilaksanakan di SD Negeri Kaliwiru Semarang dengan mengambil judul : "Peningkatan Hasil Belajar IPA Materi Hubungan Antar Komponen Ekosistem melalui Media Pembelejaran Audio Visual (Penelitian Tindakan Kelas Pada Peserta Didik Kelas V SD Negeri Kaliwiru Kecamatan Candisari Kota Semarang Tahun Pelajaran 2020/2021)“. Maka peneliti dapat menyimpulkan yaitu penggunaan media audio visual pada pembelajaran IPA tentang hubungan antar komponen ekosistem dapat meningkatkan aktivitas peserta didik ke arah yang positif. Penggunaan media audio visual dapat meningkatkan hasil belajar peserta didik. Hal ini dapat dilihat dari data hasil observasi rata-rata dan persentase ketuntasan dari hasil post test belajar peserta didik pada setiap siklusnya mengalami peningkatan.. Hal ini juga meningkatkan pemahaman peserta didik materi pembelajaran IPA materi hubungan antar komponen ekosistem.

Dari uraian di atas dapat disimpulkan bahwa penggunaan media pembelajaran audio visual dapat meningkatkan aktivitas dan hasil belajar peserta didik.

\section{DAFTAR PUSTAKA}

Arsyad,Azhar. (2014). Media pembelajaran. Jakarta: Rajawali Pers.

Djamarah, Syaiful Bahri \& Aswan Zain. 2010. Strategi belajar mengajar. Jakarta : Rineka Cipta.

Depdiknas. 2004. Kualitas Pembelajaran. Jakarta: Pustaka Media

Depdiknas.2007.Naskah Akademik Kajian Kebijakan Kurikulum Pendidikan Kewarganegaraan. Jakarta: Depdiknas Badan Penelitian dan Pengembangan Pusat Kurikulum

Sadiman, Arief S. dkk. (2012). Media pendi-dikan: pengertian, pengembangan, dan pemanfaatannya. Depok: Rajawali Pers.

Samatowa. Usman. 2006. Bagaimana Pembelajaran IPA di SD. Jakarta: Depdiknas.

Sanjaya, Wina. (2012). Penelitian pendidikan jenis, metode dan prosedur. Jakarta: Prenada Media Group.

Sanjaya, Wina. (2016). Media komunikasi pembelajaran. Jakarta: Prenada Media Group.

Sukiman. (2012). Pengembangan media pembelajaran. Yogyakarta: Pustaka Insan Mandiri.

Susanto, Ahmad. (2016). Teori belajar \&pembelajaran di sekolah dasar. Jakarta: Prenada Media Group. 